\title{
CENTRE FOR ECONOMIC POLICY RESEARCH
}

\author{
Australian National University
}

DISCUSSION PAPERS

Household Saving and Full Consumption over the Life Cycle Patricia Apps ${ }^{1}$ and Ray Rees ${ }^{2}$

DISCUSSION PAPER NO. 428

March 2001

ISSN: 1442-8636

ISBN: 0731522923

${ }^{1}$ Economics Program, Research School of Social Sciences, The Australian National University, ACT 0200, patricia.apps@anu.edu.au; ph: 61261254235

${ }^{2}$ University of Munich and University of York. 


\section{CONTENTS}

Page

Abstract iii

1 Introduction $\quad 1$

2 Some Evidence on Life Cycle Profiles 3

3 The Model $\quad 12$

4 Empirical Specification $\quad 16$

5 Within-period Demand System $\quad 18$

6 Policy Simulations $\quad 20$

7 Conclusions $\quad 24$

Appendix A $\quad 26$

References $\quad 28$

Tables $\quad 30$

$\begin{array}{ll}\text { Figures } & 38\end{array}$ 


\begin{abstract}
This paper extends the standard model of life cycle consumption, saving and labor supply in a number of directions. First, it argues that consumption should be defined as expenditure on household production as well as on market goods, that is, we are interested in life cycle profiles of full consumption. If this is done, several well-known puzzles concerning life cycle consumption behaviour are resolved. Secondly, we stress the importance of the heterogeneity of household behaviour in respect of female labour supply and saving, and provide evidence that these are very closely related across households. Finally, we formulate theoretical and empirical models incorporationg these ideas and use them to show that policy changes, such as a reduction in the progressivity of income taxation, can have effects that contrast sharply with those suggested in the existing literature.
\end{abstract}

JEL classification: D13, D91, H31, J22

Key words: saving, household production, full consumption, life cycle

Acknowledgements: We are grateful to participants at seminars at the Australian National University, the Humboldt University, Berlin, and the University of Kiel, as well as to Achim Wambach for comments on earlier versions of this paper. The usual disclaimer applies. We would like to thank Margi Wood for programming assistance and data management. The research was supported by an Australian Research Council grant. 


\section{Introduction}

The core of the life cycle model ${ }^{1}$ of consumption choice is the hypothesis that the household chooses its consumption at any point in time in the light of its entire lifetime income stream, using the capital market to decouple current consumption from current income, so as to keep its discounted marginal utility of consumption constant over time. Almost invariably, "consumption" is expenditure on goods and services bought in markets, and the income stream that appears (usually exogenously) in the model is market wage income. When the predicted consumption and saving paths are compared to the data there are striking dixerences, which are then presented as puzzles in need of explanation. Two of the most important are: the excess sensitivity of consumption to income, in the sense that current consumption seems to track current income more closely than would seem to be implied by optimally relating consumption to lifetime income; and the occurrence of larger falls in consumption upon retirement than seem to be consistent with the model $^{2}$.

However, as a number of authors have pointed out ${ }^{3}$, the consumption and income variables de..ned in these models are in fact only components of the actual total consumption and income magnitudes. Households allocate their time not just between work and (pure) leisure, but also between market and household labour supply, which may be close substitutes ${ }^{4}$. Rede..ning consumption in the model as the total value of the consumption of market and domestically produced goods, which we here call full consumption, can resolve the excess sensitivity puzzle. The household may well be choosing its full consumption path to maintain a constant marginal utility of consumption expenditure, but this is quite consistent with the observed correlation

\footnotetext{
${ }^{1}$ For a comprehensive survey of the theory and evidence see Deaton (1992). See also the interesting survey by King (1985) and accompanying comment by Diamond (1985), who both emphasise, as we do in this paper, the heterogeneity of household consumption behavior.

${ }^{2}$ For presentation and discussion of this puzzle see in particular Banks, Blundell and Tanner (1998). We provide a resolution of it in the next section of this paper.

${ }^{3}$ See, for example B axter and J ermann (1999), B enhabib, Rogerson and Wright (1991), M cG rattan, R ogerson and Wright (1997), and Rupert, Rogerson and Wright (1995),(1996).

${ }^{4} \mathrm{~T}$ he importance of these substitution possibilities has been emphasised by Benhabib et al., Mcgrattan et al., and Rupert et al., who show theoretically and empirically the signi..cant exects they can have in real business cycle models.
} 
between current market wage income and market consumption ${ }^{5}$. The evidence we present in this paper shows that changes in female labour supply, associated with the basic transitions in the life cycle of the household and corresponding changes in the degree of substitution of market for domestic outputs, are the major determinants of consumption and saving. M ore importantly, however, there is a very high degree of heterogeneity of households in these respects, and the description and explanation of this, as well as an analysis of some of its consequences for policy, are the major themes of this paper $^{6}$.

M ost of the discussion of the life cycle model takes place in the "representative agent" framework. However, for purposes of empirical estimation and policy analysis it is important to construct models that allow for and explain the diversity of behaviour that in reality exists. If heterogeneity is important, then aggregate behaviour will not in general be well explained or predicted by aggregate variables. Policy changes, such as reductions in the degree of progressivity in the tax structure, even if revenue neutral ${ }^{7}$, can have important exects on saving, via their dixerential incidence across household types ${ }^{8}$.

We want to pursue the implications of two points. First, households show an important kind of diversity in their labour supply behaviour, in that there is wide variation in the market labour supply of the secondary earner. Secondly, this labour supply diversity seems to be associated with dixerences in saving behaviour. As we show below, most saving appears to be carried out by households in which there is a signi..cant market labour supply of

\footnotetext{
${ }^{5}$ T his argument could be interpreted as rejecting the usual assumption of the separability of leisure and consumption that underlies the standard result, on the basis of a more careful characterisation of the possible uses of time not spent in market work. This is made clear in Baxter and J ermann (1999), who argue that as the wage rate increases over the life cycle, the price of domestic goods rises relative to market goods, causing consumption of the latter therefore to increase with income. This resembles the argument in Heckman (1974), who showed that the positive correlation between current income and consumption over the life cycle obtained by Thurow (1969), would be generated, in the non-separable case, by the age pro..le of wage rates. In this paper, we propose a somewhat dixerent explanation of the process of substitution between domestic and market consumption over the life cycle.

${ }^{6} \mathrm{~T}$ his heterogeneity is not taken into account in the papers discussed in the previous footnotes.

${ }^{7}$ In a companion paper to this, A pps and R ees (1999c), we analyse this question further.

${ }^{8} \mathrm{~T}$ his is in addition to the fact, shown in McGrattan et al., that introducing domestic production "generates dixerent predictions than similar models without home production".
} 
the secondary earner. The standard modelling framework, in which the only explanatory variables are demographics, wage rates and non-labour incomes, cannot account for these across-household variations. The aim of this paper is to construct a life cycle model which can provide a theoretical and empirical basis for these observations, and then show how it can be calibrated and used to analyse the exects of the kinds of policy changes that are currently under discussion in a number of countries. We base our explanation of acrosshousehold variation in female labour supply on dixerences in human capital, which cause variation in productivity in domestic production ${ }^{9}$.

In the next section we present life cycle pro..les of consumption, saving and labour supplies, obtained by merging information on income, household expenditure and time use available in three dixerent data sets. The results suggest a pattern of consumption over the life cycle that is very dixerent from that obtained by studies of consumption expenditure on market goods alone. The following section then presents a model of the household's decisions on consumption, saving and labour supplies over the life cycle. We go on to formulate a simpli..ed version of the model in Section 4 and we estimate the behavioural parameters for an empirical speci..cation of the within-period demand system set out in Section 5. In Section 6 we use the estimated parameters to analyse the exects of changes in the system of income taxation on saving over the life cycle. Section 7 concludes.

\section{Some Evidence on Life Cycle Pro..Les}

We ..nd it most useful to begin by expressing the life cycle not in terms of years, but rather in terms of six phases, which seem to us to capture the major transitions in a household's lifetime. These are:

\footnotetext{
${ }^{9}$ T hus as B ecker points out: "Human capital might [...] change the productivity of time and goods used in producing household consumption or in producing additional human capital itself". Becker (1976), p126. The importance of domestic relative to market productivity is also stressed by Benhabib et al., who argue: "When individuals are able to substitute between market and nonmarket production over time, volatility in market activity can arise because of relative productivity dixerentials between the two sectors, and not just absolute productivity shocks". Here we introduce domestic human capital as an explanatory variable capturing dixerences in domestic productivities which may be due to a range of factors, as well as to previous human capital investments or inherent skills. The modelling approach is an extension of Apps and Rees (1988), (1999a,b).
} 
2 Phase 1: the adult household members are of working age and do not yet have children;

2 Phase 2: the household has children of pre-school age;

2 Phase 3: the children are of primary school age;

2 Phase 4: the children are of high school age or have left school;

2 Phase 5: the adults are still of working age but the children have left home;

2 P hase 6: the adults are retired.

I deally panel data are required to compute life cycle consumption, saving and labour supply pro..les de..ned on these phases. Given that panel data are not available, we use micro-level cross section data. We draw information on consumption, saving, wage rates, market incomes and the allocation of time to market work, domestic work and pure leisure from three surveys of the same underlying population: the Australian Bureau of Statistics (ABS) 1993 Household Expenditure Survey (HES), the ABS 1993-4 Income Distribution Survey (IDS) and the ABS 1992 Time Use Survey (TUS). All three surveys are required because there are missing variables in each. The HES suxers from insuф cient detail on market hours of work and non-market time use. There is no consumption and non-market time use data in the IDS, and information on wages and non-labour incomes is missing in the TUS. The three surveys contain detailed information on a common set of demographic characteristics and personal attributes of family members. We combine information on two-adult households contained in these surveys, using matching samples from each. The full sample of two-adult households drawn from the HES contains 5062 records, from the IDS, 4276 records, and from the TUS, 1906 records. The empirical analysis to follow is based on records from the HES and IDS samples, augmented with information on pure leisure and domestic work using the methodology of split-sample instrumental variables. We also instrument the net wage for each partner in both samples. The merging procedures and estimation of net wage rates are described in Appendix A. ${ }^{10}$

\footnotetext{
${ }^{10} \mathrm{~T}$ he analysis, in exect, is based on a single cross section (all results are presented in 1993 prices) and therefore does not take account of cohort exects. While we recognise
} 
Table 1 reports life cycle pro..les of median net household income, expenditure on market goods, and saving, in columns 1 to 3, respectively, for the two-adult households in the HES sample. Cell size is shown in column 6 . The pro..les are broadly consistent with the existing literature. The excess sensitivity puzzle is con..rmed by the pro..les in columns 1 and 2 which show the strong tendency of household consumption to track net household income. This is brought out clearly in Figure 1. The pro..le of median consumption expenditure over phases 2 to 6 exhibits the usual "hump" shape. The highest median consumption expenditure coincides with the highest net income in phase 4. From the pro..les in these columns it is also clear that much of the hump in consumption, and the relatively low rates of saving in phases 2 to 4 , is associated with demographic variation. Saving drops sharply in phase 2 with the arrival of children and fails to rise to near its phase 1 level until phase 5 when the children have left home.

However, an analysis of this kind, based on market variables alone, gives a misleading picture of the true life cycle pro..le of consumption and, as we will show later, of the impact of demographic variation. Column 4 of the table reports median full consumption expenditure, computed as the sum of expenditure on market consumption and on domestic output. The latter is computed as the value of time allocated to domestic production, with time priced at the net wage ${ }^{11}$, using the IDS matching sample augmented with time use data as outlined in A ppendix A. ${ }^{12}$ As F igure 2 illustrates, beyond phase 1, the pro..le of full consumption expenditure does not exhibit a hump shape, but rather falls steadily over time from its highest level in phase 2. Column 5 reports median full income, computed as the income the family could earn if each partner worked full time, de..ned as 16 hours per day. While the pro..le of market consumption tracks market income, full consumption does not track full income. Full consumption is at its highest in phase 2 when wages are relatively low, then falls steadily. Thus the stylised fact of excess sensitivity does not hold for full income and full consumption.

that cohort exects can be important, it does not seem to us that they would alter the direction of our key results.

${ }^{11} \mathrm{O}$ the assumption of constant returns to scale of time inputs in household production, the expenditure on domestic consumption at the implicit price of domestic output is equal to the value of time spent in household production.

${ }^{12} \mathrm{As}$ we would expect, the distribution of cell size for the IDS is very similar to that of the HES and is therefore not reported. 
Table 2 reports mean male and female market hours, domestic hours and total hours of work, in columns 1 to 6 , respectively, using data on hours of market work and merged information on time use in the IDS sample. The results are illustrated in ..gure 3. If we compare the time allocation pro..les in this table with those for consumption in Table 1, it is immediately clear that much of the divergence between market consumption and full consumption across phases 1 to 5 rełects changes in female labour supply or, more speci..cally, the reallocation of time from market work to domestic work by the secondary earner after the arrival of children. In phases 1 to 5 , there is relatively little variation in male market hours but large changes in the hours of the female partner. While market consumption tracks market income, the latter tracks female labour supply. Note also that female market work varies inversely with domestic work. This suggests that the two types of work become close substitutes with the arrival of children. >From phase 1 to 2 female market hours fall by almost two-thirds and do not return to their phase 1 level at any later phase. While this fall in labour supply is associated with the arrival of children, we suggest that the key point is that entry into phase 2 generates a demand for a good for which there is a close substitute at home. Child care requires a large input of time, whether bought on the market or supplied domestically, and the two are likely to be close substitutes ${ }^{13}$.

The peak in full consumption in phase 2 is perhaps surprising, given that there are fewer children in this phase than in phase 3 , and wage rates are typically lower. Note also that it is associated with a peak in total hours of work. An explanation for both is that in this phase, access to market child care is restricted, with good quality child care diф cult to ..nd at a reasonable price, while capital market conditions make it very costly to ..nance child care by borrowing. Thus the household's optimal choice is to reallocate the mother's time from market to household, since she generally faces a lower net wage rate, and for both parents, but especially the mother, to work longer hours in total in phase 2.

In later years, the cost of children to parents is substantially reduced by public funding of education and the day care it provides. In other words, when the child reaches school age the public education system takes over many of the child-minding activities that the household itself has to undertake for pre-school children. This allows the female partner to enter the work

\footnotetext{
${ }^{13}$ This point is emphasised for example in Rupert, Rogerson and Wright (1995).
} 
force more easily in phase 3 . The exect is accentuated in phase 4 when the demands of children for services requiring direct time is much lower than in earlier phases. Household income, labour supply and market consumption expenditure all peak in phase 4, with teenaged children living at home, while saving is at its peak in the following phase, when the children have left home but market labour supply is still high. Thus the pro..le of full consumption and saving over phases 1 to 5 may, to a signi..cant extent, be an outcome of capital market constraints and variation in the public funding of the costs of children.

Turning to the results for phase 6 , we would suggest that taking account of the fact that domestically produced goods are generally substitutes for market goods also oxers a simple resolution of the retirement-consumption puzzle. Banks, Blundell and Tanner (1998) show that the fall in (market) consumption on retirement is much larger than can be explained by the reduction in work-related expenditures - travel costs, clothing and so on - and suggest "unanticipated shocks" upon retirement, for example learning that one's pension is smaller than expected, as a possible explanation. It seems more consistent with the life cycle model however to argue that full consumption remains relatively stable, and what we observe is a large substitution of household for market goods, due of course to the fact that on retirement all the household's working time is now devoted to domestic production. This also explains why, in categories such as expenditure on buying food that is prepared and consumed at home, Banks, Blundell and Tanner ..nd a signi... cant fall. There is simply a substitution of own time for market expenditure, a reversal of the "switch to convenience foods" example, that was so much used in the early discussions of the B ecker household production model. This is con..rmed by the results in Tables 1 and 2 . The decline in full consumption from phase 5 to phase 6 is small relative to that in market consumption, due to the increase in the allocation of time to domestic work, particularly by the male partner. ${ }^{14}$

Overall, these data suggest that the excess sensitivity of market consumption to household net market income is simply a refection of the exect of a household's decision to have children, on female labour supply on the one hand, and on the composition of full expenditure as between household and

\footnotetext{
${ }^{14} \mathrm{~N}$ ote that the data are likely to understate the true level of consumption in the retirement phase because publicly funded and subsidised services available to those eligible for the age pension are not included.
} 
market goods on the other.

As stated in the Introduction, the major concern of this paper is the heterogeneity of labour supply and saving behaviour among households with the same wage rates, non-labour incomes and demographics, which is concealed in the overall average ..gures considered above. We argue that many studies in the existing literature are misleading, because they simultaneously omit household production and ignore the evident heterogeneity in household consumption and saving behaviour. To illustrate, we .rst examine the empirical importance of heterogeneity, using data for matching samples selected on the additional criterion that the male partner is employed. Since information on the productivity of domestic time is missing, the dimension along which we de..ne heterogeneity is female labour supply. The idea, as we make more precise in the next section, is that households choose lifetime paths of male and female labour supplies, saving and consumption of household and market goods, given wage rates, interest rates and productivities in household production. Dixerences in domestic productivities across households lead to dixerences in choices of these endogenous variables, for households facing the same wage and interest rates.

I deally we would like to distinguish between: those households in which female labour supply is zero or "marginal" 15 throughout the life cycle, which we refer to as "traditional households"; those in which the female has a signi..cant and relatively large labour supply over the entire life cycle, which we call "non-traditional" households; and those which switch from being traditional to non-traditional at some stage of the life cycle, for example, once the children have started primary school. This categorisation requires panel data. Since we are limited to cross section data, we partition households into three groups, which we assume rełect the underlying dixerences in domestic productivities that determine household type. These are:

2 traditional households, where the wife supplies no market labour or has no labour income;

2 non-traditional households, where the wife works part time (PT);

2 non-traditional households, where the wife works full-time (FT).

Tables 3 and 4 present income, consumption, saving and time allocation pro.. les for each of these household types across phases 2 to 5 of the life cycle,

\footnotetext{
${ }^{15}$ In the Heckman (1995) sense.
} 
for matching HES and IDS samples containing households with an employed male partner. The HES sample contains 2475 household in these phases, of which 1046 (42.26 per cent) are traditional, 665 (26.89 per cent) are nontraditional $\mathrm{FT}$, and the remaining 764 (30.87 per cent) are non-traditional PT. Table 3 reports the pro..les for the same variables as in Table 1 for each household type. Table 4 gives data means for market and domestic hours of work in the format of Table 2 using the matching IDS sample ${ }^{16}$. The HES cell size is shown in column 6 of Table 3 .

From the results it can be seen that there is relatively little within-phase variation in the average number of children across the three groups. There is also relatively little variation in full incomes, full consumption and in male hours of work in each phase. This contrasts with large dixerences in the market and domestic hours of work reported for the female partner. There are also strikingly large dixerences in saving. Non-traditional households not only have higher net market incomes, they also have much higher levels of saving, particularly those with a full time employed female partner. ${ }^{17}$ These results support the hypothesis that households with the same wage rates and non-labour incomes (or full incomes), and with the same family commitments, make very dixerent labour supply and saving decisions. And those that specialise in market production also save more than those that specialise in domestic production. ${ }^{18}$

The existing literature contains a number of studies which examine econometrically how consumption over the life cycle is in $¥$ uenced by labour market status, especially female labour force participation, as well as by demograph-

\footnotetext{
${ }^{16}$ T he small positive mean hours of market work for traditional households in phases 2 to 5 rełect records reporting zero labour income but positive labour supply.

${ }^{17} \mathrm{~N}$ ote that income generated by household production is inherently non-saveable.

${ }^{18} \mathrm{~T}$ hese...ndings are open to the objection that the reported dixerences in saving between the groups are overstated, because switching households cannot be identi..ed. That this could be a signi..cant problem is evident from the change in cell size with phase in life cycle. For example, there are considerably fewer non-traditional FT families in phase 2 than in phases 3 and 4. Comparing saving medians across the three groups can therefore be expected to overstate the true level of saving by non-traditional households and understate that of traditional households. A reason for this could be, for example, that a switching household, classed as traditional in stage 2, may be saving less in stage 2, because it plans to save more later. Conversely, a switching household, classed as non-traditional in stage 5 , may be saving more at that stage to pay ox debt incurred in an earlier stage. However, we would suggest that these exects would need to be implausibly large to oxset fully the dixerences in saving behavour indicated by these cross section comparisions.
} 
ics and age cohort ${ }^{19}$. These studies do not support the preceding hypothesis. They note that female labour force participation appears to have an important exect on the sensitivity of consumption to the interest rate, though it is unclear whether this is due to the fact that there are positive costs associated with going out to work, or whether female participation increases expected income and therefore current consumption. The literature seems however to point to the conclusion, expressed explicitly by Attanasio and Banks (1998) as

"an increase in female labour force participation is linked to a decrease in measured saving"

We regard this ..nding as misleading and contrary to the evidence we have presented. If we consider two households with the same household net income, in one of which the wife works and in the other not, then due to costs of going out to work, saving in the former household may be lower. But this is the wrong comparison. If one conditions ..rst on the primary earner wage and nonwage income, as well as on the female wage and on demographics, one ..nds that households in which the wife works save signi..cantly more than those in which she does not, as indicated in the preceding tables. In other words, the marginal propensity to save out of the second earner's income is very high, despite the presence of costs of going out to work. This is masked in the former case by the fact that saving increases with primary earner income, so a household with a non-working wife and a high-wage primary earner may save a little more than a household with two lower-wage earners and about the same household income. But to isolate the incremental exect of the female labour supply decision we should, at the very least, control for the primary earner wage.

The studies cited fail to do this because, in the ..rst instance, the underlying structural model of household decision making with respect to consumption and saving assumes that these endogenous variables depend only on market wages, the interest rate and demographics. There is no exogenous variable, such as the price of domestic output, which can explain variation in these endogenous variables while holding wages rates and demographics constant. In the second instance, in empirical work on life cycle consumption behaviour, the convention is to assume within-period separability between

\footnotetext{
${ }^{19}$ See, for example, Attanasio and Banks (1998), and Blundell, Browning and Meghir (1994).
} 
consumption and leisure, with both measured incorrectly because time spent on domestic work is aggregated with pure leisure $\mathrm{e}^{20}$. In other words, the misleading comparisons in the existing literature are a logical consequence of a modelling approach which ignores heterogeneity among households with the same wage rates and demographics, and, simultaneously, omits expenditure on domestic production in the measure of the household consumption variable.

The empirical signi..cance of the dixerence in the two approaches - ours and that of the existing literature - can be illustrated by comparing the distribution of the household groups by net household (market) income and by full income, and contrasting their saving pro..les. Table 5 compares the quartile distribution of each household group by net household income (section a) and by net full income (section b), and reports quartile medians of saving and saving rates for each household group. The results are based on the more restricted HES sub-sample used to derive the pro..les in Table 3.

From the table it can be seen that the two income variables give entirely dixerent distributions of the household groups. Traditional households are concentrated in the lower quartiles of the household income ordering, and non-traditional in the upper quartiles. In contrast, the household groups tend to be evenly distributed across full income. The confict is due to the fact that household market income is negatively related to domestic consumption. Non-traditional households with relatively low wage rates but higher levels of expenditure on market consumption appear in the same household income quartile as traditional households with higher wage rates and higher levels of domestic consumption. In the full income ranking, households with the same wage rates and non-labour incomes appear in the same quartile. Comparing the saving ..gures for the three household groups in each quartile, as in Figures 4 and 5, it is immediately apparent that the household market income ranking either reverses or understates the dixerences indicated by the full income ranking, because it fails to control for wage rates. The full income ranking suggests that, holding wage rates constant, non-traditional households tend to save far more than traditional households in each quartile.

\footnotetext{
${ }^{20} \mathrm{~T}$ hat is, studies which try to estimate the life cycle allocation of household consumption require a within-period demand system that includes consumption of domestic goods. This same point is also made by Benhabib, Rogerson and Wright, (1991), and by M cGratton, Rogerson and Wright (1997), in the context of macroeconomic growth and business cycle models.
} 
In the next section, we present a modelling approach which attempts to address these issues. In this model, we distinguish between households on the basis of secondary earner market labour supply, using human capital and associated productivity in household production as the variable that accounts for across-household variation in this respect.

\section{The Model}

The household has a lifetime of $T+1$ periods, with $t=0 ; 1 ;: ; ; T$ denoting the period. In line with the empirical discussion in the previous section we distinguish six phases of the household's life cycle, which form a partition of the set of time periods:

$2 A_{1}=f 0 ;: ; ; \iota_{1} g$ : there are no children and the household has a relatively strong preference for the market good;

${ }^{2} A_{2}=f_{i_{1}}+1 ;:: ; i_{2} g$ : there are pre-school children and the household has a relatively strong preference for the domestic good;

${ }^{2} A_{3}=f_{i_{2}}+1 ;:: ; i_{3} g$ : the children are in primary school or early high school years, and the household's preference for market goods is higher than in the second phase but lower than in the ..rst;

${ }^{2} \hat{A}_{4}=f_{i_{3}}+1 ;: ; i_{4} g:$ the children are at high school or have left school and the household's preference for market goods is higher than in the third phase but lower than in the ..rst;

${ }^{2} A_{5}=f_{\iota_{4}}+1 ;: . ; i_{5} g:$ the children have left home, both adults are of working age, there is again a high preference for market goods;

$2 A_{6}=f_{i 5}+1 ;: ; ; T g:$ adults are retired and supply no market labour, preferences are as in $A_{5}$ :

There are three household types, indexed by $\mathrm{h}=1 ; 2 ; 3$; which dixer according to the value of the female domestic productivity parameter $k_{\text {ht }}$. The notation also allows this productivity to vary over time. However, the ranking of the household types in terms of this parameter does not change over time. 
The household maximises its utility over its lifetime

$$
u_{h}={ }_{t=0}^{X^{\top}} 1 / 2 u\left(X_{h t} ; y_{h t} ; z_{1 h t} ; z_{2 h t} ; \dot{A}_{j}\right)
$$

where $1 / 2$ is a time preference discount factor, $\mathrm{x}$ is consumption of the market good, $y$ is consumption of the domestic good, $z$ is consumption of pure leisure, and the phase indicator $\hat{A}_{j}, j=1 ; \ldots ; 6$ determines tastes for household $h$. Thus the phase of its life cycle the household is in determines its preferences over domestic and market consumption and leisure. Note that households are assumed to have identical preferences in any given phase of the life cycle. Each individual $i=1 ; 2$ in the household has the time constraint

$$
a_{\text {iht }}+l_{\text {iht }}+z_{\text {iht }}=A \quad h=1 ; 2 ; 3 ; t=0 ;:: ; T
$$

where I denotes a market labour supply, a the supply of labour to domestic production and $\mathrm{A}$ is total available time. The production functions of the household good are

$$
y_{h t}=f\left(a_{1 h t} ; a_{2 h t} ; k_{h t}\right) \quad h=1 ; 2 ; 3 ; t=0 ; \ldots ; ;
$$

Note however that for $\mathrm{t} 2 \dot{A}_{6}$, the retirement phase, $\mathrm{l}_{\mathrm{int}}=0$, and so in periods corresponding to this phase $a_{i n t}$ and $z_{i h t}$ are the only time use variables. The budget constraints in each period are

$$
\begin{aligned}
x_{h t}+s_{t} & ={ }_{i=1}^{X^{2}} w_{i t} l_{i h t}+(1+r) s_{t_{i} 1} \quad t 2 \dot{A}_{j} ; j=1 ;:: ; 5 \\
x_{h t}+s_{t} & =P+(1+r) s_{t_{i} 1} \quad \text { t } 2 A_{6} \\
s_{T} & =0=s_{i} 1
\end{aligned}
$$

where $w_{\text {it }}$ is i's net of tax market wage at $t$ (we thus allow the possibility of changes in the wage over time), $s_{t}$ is saving $(>0)$ or dissaving $(<0)$ at $\mathrm{t}=0 ; 1 ;:: ; \mathrm{T}, \mathrm{P}$ is the lump sum pension payment per period and $\mathrm{r}$ is the oneperiod market interest rate, assumed constant over time. To be consistent with the assumption that there is no bequest motive, which implies saving at zero in the last period of life, we also assume there is no inherited wealth, so that assets are also zero at the beginning of period 0 . These constraints can be collapsed in the usual way into the wealth constraint

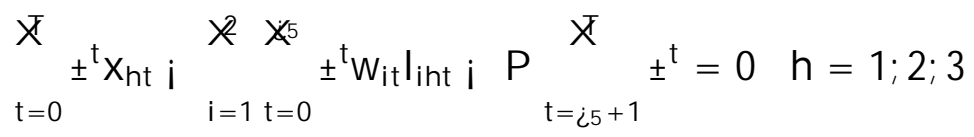


where $\pm=(1+r)^{i}{ }^{1}$ is the market discount factor and $i_{5}+1$ is the ..rst period of the retirement phase.

The household maximises (1) subject to (2), (3) and (7). The ..rst order conditions (assuming only interior solutions) for this are

$$
\begin{aligned}
& 1 / 2 \frac{@}{@ Q_{h t}} i, h^{ \pm}=0 \quad h=1 ; 2 ; 3 ; t=0 ;:: ; T \\
& { }_{1 / 2} \frac{@ i}{@ / h t} i^{1}{ }_{h t}=0 \quad h=1 ; 2 ; 3 ; t=0 ;:: ; \mathrm{T} \\
& { }_{n} W_{i t} \pm^{ \pm} ; \quad 1 / h t=0 \quad i=1 ; 2 ; h=1 ; 2 ; 3 ; t=0 ;:: ; 25 \\
& 1 / 2 \frac{@ i}{@_{\text {int }}} ; 1 / \text { ht }=0 \quad i=1 ; 2 ; h=1 ; 2 ; 3 ; t=0 ;:: ; \mathrm{T} \\
& { }^{1}{ }_{\text {ht }} \frac{@}{\oint_{\text {int }}} ; 1 / \text { iht }=0 \quad i=1 ; 2 ; h=1 ; 2 ; 3 ; \mathrm{t}=0 ; \ldots ; \mathrm{T}
\end{aligned}
$$

together with the constraints. Here,$h$ is the household's marginal utility of wealth and the ${ }^{1} \mathrm{ht}$, the Lagrange multipliers associated with the production function constraints, give the discounted marginal utility of the domestic output. The $1 /$ Ant are the Lagrange multipliers associated with the time constraints (2).

We see from (8) that the marginal utility of consumption of the market good, weighted by the ratio of discount factors $\left(1 / \mathbb{t}^{\mathrm{t}} \mathrm{t}\right.$, must be constant over time, and equal to the marginal utility of wealth, but since this marginal utility of market good consumption is in general a function of the consumption of both market and household goods, this does not imply constancy of the time path of market consumption, even within a given phase $\dot{A}_{j}$. The optimal consumption paths depend on the implicit price of the domestic good (recall the market good is numéraire). Thus, de.ne

$$
p_{h t}, \frac{{ }^{1} h t}{, n^{ \pm}}=\frac{w_{i t}}{\oint f} \quad t=0 ;:: ; i_{i h t}
$$

as the current value implicit price of the domestic good, which is equal to the undiscounted marginal cost of the domestic good. In general this will depend on the level of output of the domestic good, as well as on the aftertax wage rates and the marginal productivities, which in turn depend on the productivity parameters $k_{\text {ht }}$. The...rst two conditions then yield the standard condition for within-period consumption choices

$$
\frac{@ d_{i}=@ y_{h t}}{@_{l}=@ x_{h t}}=p_{h t}
$$


The time paths of consumption of both goods will depend on how this price varies over time, as well as on how transitions between phases of the life cycle change the relative preferences for market and household goods. Differences across households in this price will lead to dixerences both in their within-period time and consumption allocations and in their time pro..les of consumption, even given identical preferences across households. At given wage rates, a household with higher productivity in household production will have a lower value of this price and therefore will have a higher demand for domestic output, assuming this is not a Gixen good. This does not necessarily imply that this household will have a higher domestic time input lower market labour supply - however, because higher productivity implies that a given domestic output can be produced with a smaller time input. Thus we cannot say a priori that traditional (non-traditional) households are those with higher (lower) productivities in domestic production. ${ }^{21} \mathrm{~W}$ ith a given domestic productivity, the higher the wage rate, the higher the price of the domestic good, but since household income is also higher, the net exect on the demand for the domestic good is ambiguous. However, the assumption that labour supply increases with the wage is equivalent in this model to assuming that demand for the household good falls with wage-induced increases in its price.

In the retirement phase, the household is in a sense at a corner solution with zero values of market labour supplies. In that case the opportunity cost of time spent in household production is not the wage rate, but the current money value of foregone leisure, $!_{i n t}{ }^{\prime} 1 / h_{h}={ }_{h} \pm$. Thus we de. ne the implicit price of the domestic good now as

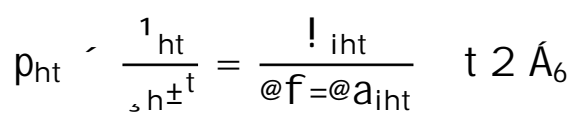

Then, condition (14) still applies, with the implicit price of domestic output now determining the time paths of consumption of the market and household goods and leisure in the retirement phase. Accumulated savings and the $\ddagger$ ow of pension payments also play an important role of course.

The conditions (8) - (12) assume no corner solutions, and in particular (10) rules out (except trivially) households with a zero market labour supply. For these however we simply have the condition

$$
\mathrm{W}_{2 \mathrm{t}} \cdot !_{2 \mathrm{ht}}
$$

\footnotetext{
${ }^{21}$ For a formal proof, see A pps and R ees (1999b).
} 
and it is the implicit price of the household good as de..ned in (15), and not as in (13), that determines the time paths of consumptions.

We now go on to formulate a simpli..ed version of this model, which can be estimated on the available data. We will then use the parameter estimates to calibrate the model and simulate the exects on household saving and labour supplies of various types of policy changes.

\section{Empirical Speci..cation}

To make the model tractable, while retaining the aspects of main interest, we make the following assumptions:

1. Each individual has ..xed pure leisure.

2. The production function for domestic output is linear and can be written

$$
y_{h t}={ }_{i=1}^{x^{2}} k_{i n t} a_{i h t}
$$

3. The primary earner has a ..xed labour supply, $\mathfrak{l}_{1 \mathrm{ht}}$; and therefore a ..xed time allocation to domestic production, $a_{1 h t}$ : This implies that the price of the domestic good is determined by the productivity of the secondary earner.

4. Preferences and all exogenous variables are constant within a phase.

5. The indirect utility function takes the form

$$
u_{h t}=a_{h j}\left(p_{h t}\right)+\frac{\log c_{h t}}{b_{h j}\left(p_{h t}\right)} \quad h=1 ; 2 ; 3 ; j=1 ;:: ; 6
$$

where $p_{n t}$ is the implicit price of the domestic good de..ned as

$$
p_{\mathrm{ht}}=\frac{\mathrm{w}_{2 \mathrm{t}}}{\mathrm{k}_{2 \mathrm{ht}}}
$$

The taste changes corresponding to changes in life cycle phases are assumed just to change the parameters in the indirect utility function directly.

It is useful to recast the solution of the model presented in Section 3 as a two-step procedure. First de..ne full consumption as

$$
c_{h t}=x_{h t}+p_{h t} y_{h t}
$$

Taking $c_{h t}$ and $p_{n t}$ as given for each $t$ means that (20) can be regarded as a within-period budget constraint. Solving for within-period consumptions 
and labour supplies yields the indirect utility function in (18). The wealth constraint can be rewritten in "full wealth" form as

$$
{ }_{\mathrm{t}=0}^{X^{\top}} \pm^{ \pm} \mathrm{C}_{\mathrm{ht}}={ }_{\mathrm{t}=0}^{X^{\top}} \pm_{\mathrm{i}=1}^{\mathrm{X}^{2}}\left(\mathrm{w}_{\mathrm{it}}\left(\mathrm{A}_{\mathrm{i}} z_{\mathrm{int}}\right)\right)+\mathrm{P}_{\mathrm{t}=i_{5}+1}^{X^{\top}} \pm^{t^{\prime}} \mathrm{W}
$$

where "full wealth" $W$ is exogenous (given the assumption that pure leisures are exogenous and constant), and depends on after-tax wage rates and pension payments.

The household then solves the intertemporal optimisation problem

$$
\begin{aligned}
& \max _{\mathrm{ct}_{\mathrm{t}}}{ }_{\mathrm{t}=0}^{X^{\top}}{ }_{1 / 2 \mathrm{v}_{\mathrm{ht}}\left(p_{\mathrm{ht}} ; c_{\mathrm{ht}}\right)}=\mathrm{v} \\
& \mathrm{s:t:}{ }_{\mathrm{t}=0}^{X^{\top}} \pm^{\mathrm{t}} \mathrm{c}_{\mathrm{ht}}=\mathrm{W}
\end{aligned}
$$

The solution to this problem yields the life cycle and across-household pro..les of full consumption, and the estimated demand and labour supply functions within periods can then be used to derive pro..les of market and domestic consumption, saving and secondary earner labour supplies. Given the assumed functional form for indirect utility, the ..rst order conditions for this problem are

$$
\begin{aligned}
\frac{1 / 2}{ \pm b_{h j}\left(p_{h t}\right) c_{h t}} & =, h \quad h=1 ; 2 ; 3 ; t 2 \dot{A}_{j} ; j=1 ;:: ; 6 \\
{ }_{t=0}^{X^{\top}}{ }^{ \pm} c_{h t} & =W
\end{aligned}
$$

The important thing to note is that the marginal utility of full consumption in each period depends on the price of the domestic good, $p_{n t}$, and therefore on the secondary earner's wage rate and the productivity parameter $k_{\text {ht. }}$. Thus the entire time pro..le of full consumption, as well as its allocation within each period as between market and domestic consumption, depends on this parameter. The solution of the system is given very simply by

$$
\begin{aligned}
& c_{h t}=\mathbb{R}_{\mathrm{h}} \mathrm{C}_{\mathrm{hT}}
\end{aligned}
$$

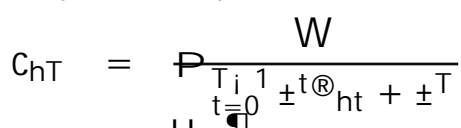

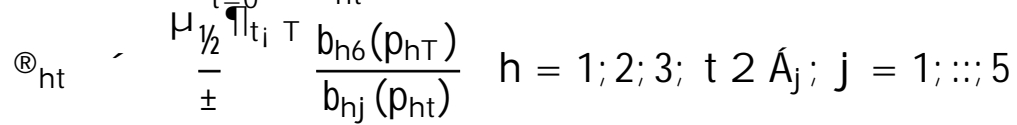


Thus, we can translate the policy changes considered in Section 5 into changes in the implicit prices of the household good and household wealth, use (26) to (28) to solve for the resulting time pro..les of full consumption, and then use the within-period functions to solve for market consumption, consumption of the domestic good, household saving and female labour supply.

\section{W ithin-period demand system}

The policy analysis to follow requires estimates of the preference parameters of the within-period functions. For this purpose we can select estimates from the literature or, alternatively, estimate a system on the data used in the empirical analysis in Section 2. We choose the latter strategy.

We select the Almost Ideal (AI) demand system speci..cation for the indirect utility function in (18). Suppressing the subscripts $h$ and $j$, the function takes the form

$$
u(p ; c)=(\ln (c) i \ln a(p)) \neq p(p)
$$

where $p=w_{2} \neq k$ is the implicit price of the domestic good, $c$ is full consumption and the price indexes $a(p)$ and $b(p)$ are given by

$$
\begin{gathered}
\ln a(p)=\mathbb{B}_{0}+\mathbb{B}_{y}(d) \ln p+0: 5^{\circ} y y(d) \ln ^{2} p \\
b(p)={ }^{-}(d) \ln p
\end{gathered}
$$

where $\mathbb{B}_{0}, \mathbb{B}_{y}(d),{ }_{y y}(d)$ and ${ }^{-}{ }_{y}(d)$ are parameters and, to allow for preference variation with family size, we specify $\mathbb{B}_{y}(d)=\mathbb{B}_{y}+\mathbb{B}_{y} \ln d,{ }^{\circ} y(d)={ }^{\circ}{ }_{y y}+$ ${ }^{\circ} y_{y}$ Ind and ${ }^{-} y(d)=-0+-1$ Ind, where Ind is the log of the number of children in the household. The parameter restrictions for adding up are

$\circledast(d)=1, \quad{ }_{i}(d) p=0$ and $\S{ }^{\circ}{ }_{i j}(d)=0$; for symmetry, ${ }^{\circ}{ }_{i j}(d)={ }_{j i}(d)$; and for homogeneity, $\circ_{\mathrm{ij}}(\mathrm{d})=0$.

Household demands in share form are

$$
\begin{gathered}
S_{y}=\mathbb{Q}_{y}(d)+{ }^{\circ} y y(d) \ln p+{ }^{-} y(d) \ln (c=a(p))+{ }{ }_{y} \\
S_{x}=\mathbb{R}_{x}(d)+{ }^{\circ}{ }_{x y}(d) \ln p+{ }^{-} x \ln (c=a(p))+{ }^{~}{ }_{x}
\end{gathered}
$$

where $S_{x}=x=c$, and $S_{y}=p y=c$. Given adding up, we need only estimate the share equation for the domestic good. 
We estimate the model on data for a sample of 1907 households records selected from the HES sample described previously, on criteria listed in A ppendix $A$. The sample is restricted to non-traditional households with a full time employed male partner. Since each record contains information on time use from the TUS and on net wage rates, we can compute expenditure on domestic production. However, information on domestic output, and therefore on $\mathrm{k}$, is missing and so $\mathrm{p}$ cannot be computed. To deal with this problem we estimate the model specifying the share equation in (32) in the standard form as

$$
S_{y}=\mathbb{B}_{y}(d)+{ }^{0}{ }_{y y} \ln w_{2}+{ }^{-} y \ln \left(C=a\left(w_{2}\right)\right)+\lambda_{y}
$$

where

$$
\ln a\left(w_{2}\right)=\AA_{0}+\mathbb{B}_{y}(d) \ln w_{2}+0: 5^{\circ} y y(d) \ln ^{2} w_{2}
$$

We then interpret $\gg y$ as

$$
\lambda_{y}=0: 5^{\circ} y y(d) \ln ^{2} k+\left(^{-}(d) \mathbb{B}_{y}(d) ;{ }_{y y}^{\circ}\right) \ln k+{ }^{\prime} y
$$

and attribute variation in specialisation in domestic production across households to dixerences in $k$, by setting " $\mathrm{y}=0$. The positive solution to this equation gives a value for $\mathrm{k}$ for each record which can then be used to compute the domestic price $p$ on which to base policy simulations. Note that the standard labour supply model omits the domestic price and therefore implies setting $\mathrm{k}=1.22$

The parameter estimates for phases to 1 to 5 are reported in A ppendix A. The results imply wage elasticities, evaluated at data means, of 0.0531 for households in phase 1, 0.8604, 1.0514, 0.9248 and 0.5595 for non-traditional PT households in phases 2, 3, 4 and 5, and 0.2524, 0.3345, 0.3212 and 0.1254 for non-traditional FT households in the same phases, respectively. These elasticities support the proposition that, with the presence of children, market and domestic production are relatively close substitutes. In phase 1 the female wage elasticity is close to zero. The next lowest wage elasticity for each type appears in phase 5 when the children have left home. Elasticities are, as we would expect, typically higher for married women in part time work.

\footnotetext{
${ }^{22} \mathrm{~T}$ he standard model of household labour supply assumes each partner's net wage is the price of output from an hour of domestic work as well as the price of an hour of pure leisure. This implies that each type of domestic labour - male or female - is equally productive across all households. If this assumption does not hold, we can expect parameter bias due to the omitted domestic price variables in the hours equations.
} 


\section{Policy Simulations}

We use the parameters of the demand model to explore the implications of changes in tax policy. Our aim is to illustrate the importance of taking account of the heterogeneity of household types with respect to household labour supply and saving behaviour, in analysing the exects of a policy change on these variables.

For this purpose we construct a hypothetical data set containing 18 records, one for each household type in each phase. The information for each record is based largely on the data means and medians of matching samples selected from the ABS ..les on the criteria that the reference person of the household is male and is employed in phases 1 to 5 , that both partners of households in phase 1 are employed, and that the reference person of households in phase 6 is 75 years of age or under. Applying these criteria gives a sub-sample of households in phases 2 to 5 which is the same as that used to derive the pro..les in Tables 3 and 4 . The records for these households contain the median saving and data means for market hours, domestic hours and number of children shown in these tables, with the exception of market hours for traditional households. We set market hours of work for traditional households in phases 2 to 5 to 200 hours pa. This allows us to avoid the problem of corner solutions and, as well, to capture labour supply exects for traditional households with a marginal work force attachment over the life cycle but recording zero hours on a "current" basis. ${ }^{23}$ The selection criteria for phase 1 implies there are no non-participants by choice in this phase. Each household type in phase 1 is represented by a record containing the data means for time use and median saving computed for the full subsample in this phase. The records for households in phase 6 are also identical, since the data do not allow the types to be distinguished. Saving in this last phase is set at zero. All records contain the mean net wage for each partner derived from information on earnings, market hours and taxes, as described

\footnotetext{
${ }^{23}$ Simulations which assume zero hours for the wife on the basis of "current" data for employment status and hours of work can be expected to understate the true labour supply exects for this highly responsive group. Many married women reporting their current employment status as "not in the work force" are likely to be working at other times of the year. This is evident from the fact that participation rates cited on an annual basis are typically much higher than rates based on current employment status, where the "current" period is one or two weeks. The discrepancy between annual and current rates is even greater when the latter is based on time use data obtained by diary, as in the TUS where the information is collected for two diary days.
} 
in A ppendix A. The simulations are based on the assumption that the government provides an income tested pension of $\$ 10000$ pa in retirement and that, applying the income test, only traditional households are eligible.

We consider two stylised reforms. "R eform 1" combines a 10 per cent rise in the tax rate on the wage income of the female partner and a reduction in the rate on that of the male partner set to achieve revenue neutrality. "R eform 2" does the reverse, combining a reduction of 10 per cent in the tax rate on the female's wage income with an increase in the rate on that of the male partner, again set to achieve revenue neutrality. These reforms can be interpreted as capturing the change in tax rates on the earnings of partners typical of changes in the progressivity of a tax system based on individual incomes. ${ }^{24}$ Because, in most households, the earnings of the female partner are much lower than those of the male partner, the progressive taxation of individual incomes implies lower marginal and average rates for the female partner within each household. A revenue neutral reform which reduces progressivity can therefore be represented by an increase in the tax rate on the wage income of female partners, with the proceeds used to ..nance a reduction in the rate on the wage income of male partners, as in Reform 1. Similarly, a reform which increases progressivity can be represented as one which reduces the tax rate on the female wage and raises it on the male wage, as in R eform $2 .{ }^{25}$

The ..rst step in the policy analysis is to simulate the pre-reform equilibrium. Using the parameters of the demand system in the preceding section, we ..rst solve for $\mathrm{k}$ for each record using (36) and we then use the result to compute the price of the domestic good. Next we derive the life cycle distribution of consumption, using (26) to (28) and incorporating a household equivalence scale for each phase and type ${ }^{26}$. The interest rate is set at 1 per cent and the rate of time preference is assumed to be the same as the

\footnotetext{
${ }^{24} \mathrm{As}$ in the case of the A ustralian income tax system.

${ }^{25} \mathrm{~A}$ Iternatively, Reform 1 can be interpreted as a shift from a system of individual taxation to one based on joint income, as in the US or Germany, and Reform 2 as a change in the opposite direction. For further explanation and a detailed analysis of reforms speci..ed and interpreted in this way, see A pps and Rees (1999b)

${ }^{26} \mathrm{~T}$ he equivalence scales are computed as the error terms in the pre-reform simulation of the life cycle distribution of consumption.T he results implied equivalence scales of 0.96 , $1.62,1.46,1.32,1.07$, and 1.0 in phases $1-6$ respectively. Note that the life cycle model we have speci..ed assumes a perfect capital market. This assumption may well not be realistic. In the case of imperfect capital markets the error terms can be interpreted as a measure of the exects of constraints on borrowing.
} 
interest rate. Prereform life cycle and across-household pro..les of female hours of work, net market income, full consumption expenditure and saving are reported in Table 6, columns 1 to 4, respectively.

The post-reform equilibrium values of the same variables are reported in Table 7 for Reform 1 and Table 8 for R eform 2. Column 5 of the tables gives the tax gain (loss) under the respective reforms. Note that saving, shown in column 4, is derived as the dixerence between full consumption expenditure and the sum of net market income and expenditure on the domestic good, using the results for full consumption expenditure computed by equating the marginal utility of income across the life cycle phases by substituting the $b(p)$ index of the demand system in (28).

R eform 1 has the overall exect of reducing saving for the retirement phase, in terms of present value, from an average of $\$ 18825$ to $\$ 17741$ per annum. There are dixerent exects for each household type. The saving of traditional households falls from $\$ 2841$ to $\$ 2131$. Saving by the non-traditional PT households falls from $\$ 20060$ to $\$ 19022$ and that by non-traditional FT households, from $\$ 33572$ to $\$ 32069$. The 10.00 per cent increase in the tax rate on female earnings ..nances a reduction of only 4.23 per cent in the rate on male earnings. The large gap between the two rates is due the fact that the average wage income of the female partner is less than half that of the male partner. This wage income dixerential is reinforced by the negative exect of the reform on female labour supply.

R eform 2 has the opposite exect on labour supply and saving. Overall, saving for the retirement phase rises from the pre-reform average of $\$ 18825$ to $\$ 19825$ per annum. In this case the saving of traditional households rises from $\$ 2841$ to $\$ 3482$. Saving by the non-traditional PT households rises from $\$ 20060$ to $\$ 21018$ and that by non-traditional FT households, from $\$ 33572$ to $\$ 34973$. The 10.00 per cent reduction in the tax rate on female earnings requires a rate of 4.49 per cent on male earnings for revenue neutrality. The rate increase is larger in absolute value than the 4.23 rate reduction under R eform 1 due to the positive exects of R eform 2 on female labour supply.

$>$ From column 5 of the tables it can be seen that R eform 1 implies a shift in the tax burden from traditional households to those in which the female partner has a signi...cant work force attachment. Under R eform 1 traditional households are the bene..ciaries, gaining an increase in net income in all working phases of the life cycle apart from phase 1, when both partners are employed. For non-traditional PT households, the gains for the male partner almost cancel out the losses for the female partner. Non-traditional 
FT households pay more tax in each working phase of the life cycle, in exect ..nancing the gains for traditional households. The reform reduces the present discounted value of life time wealth, averaged across the household types, to $\$ 2.82 \mathrm{~m}$, from a prereform level of $\$ 2.90 \mathrm{~m}$. Reform 2 has an opposite distributional exect in the case of each household type, and increases the mean present value of life time wealth to $\$ 2.97 \mathrm{~m}$.

The pre-reform present value of life time wealth ranges from $\$ 2.79 \mathrm{~m}$ for the traditional household to $\$ 3.04 \mathrm{~m}$ for the non-traditional FT household. The lower value for the traditional household is due primarily to the fact that the household has more pure leisure in phases 2 to 5 , and so the simulations are based on a correspondingly smaller time constraint. From Table 4 it can be seen that, for example, in phase 2 the traditional household works 4299 hours per annum, the non-traditional PT household, 4538 hours, and the non-traditional FT households, 4970. Similar dixerences carry across phase 3,4 and 5 . Since there is relatively little variation in net wage rates by household type within each phase, the households have similar full incomes, computed on the basis of a time constraint including pure leisure. Since the traditional household has signi..cantly more leisure, the net wealth dixerence between traditional and non-traditional households would be much greater, were it not for the incometested pension. In exect, the household chooses between more lifetime leisure, together with lower taxes and a pension, versus less lifetime leisure combined with higher taxes and no pension. From this perspective it seems likely that there may be a very close trade-ox between work and pure leisure, which is not rełected in the results. In other words, the wage elasticities we have estimated may seriously understate the negative exects of R eform 1 on life time labour supply and saving, and the positive exects of R eform 2 on these variables.

Since the simulations are based on household records with similar full incomes and present discounted values of life time wealth, the results do not capture distributional exects with respect to the dispersion of wealth and full incomes across households. The data suggest that the gender wage gap within a household tends to rise with the male wage, a rełection of the fact that there are very few high wage women. Turning to Table 5 in Section 2, we would therefore expect all three types of households in the top quartile of full income to be net bene..ciaries of R eform 1, because the loss incurred by the female partner would be more than oxset by the gain by the male partner. Overall, the reform would shift a greater share of the tax burden to non-traditional FT households in middle quartiles because they would, in 
exect, be ..nancing most of the gains in the top quartile, and so the negative exects on the wealth, labour supply and saving of these households would be correspondingly greater.

Distributional exects of this kind are entirely lost by an analysis which ignores domestic consumption and presents results by household market income. Non-traditional FT households with median wages are confused with much higher-wage traditional households and located towards the top quartile, as indicated in Table 5, part (a). To illustrate, Table 9 presents the quartile household income distributions of tax gains and losses for households in phases 2 to 5 under the two reforms.

The ..rst section of the table shows the distribution of the 12 records in these phases, by household income. The traditional records are concentrated in quartile 1 and the non-traditional FT records, in quartile 4. the result is that R eform 1 appears to be highly redistributional, and R eform 2 highly regressive, when in fact all records have similar full incomes and lifetime wealth. Results of this kind can misleadingly suggest a trade-ox between equity and disincentive exects on labour supply and saving, when none in fact exists.

\section{Conclusions}

In this paper we have been able, by merging three data sets, to examine the relationships among income, consumption, saving, male and female labour supplies, wage rates and family size for a cross section of households. We de.ned the life cycle not in terms of years, but rather in terms of the phases through which a typical household moves. We showed that the muchdiscussed "excess sensitivity" of market consumption to market income does not apply to full consumption and income. Full consumption rises sharply when couples ..rst have children, because of the high cost and/ or poor availability of market substitutes to domestic child care and capital market constraints, then declines slowly and steadily over the life cycle. The "excess sensitivity" of market consumption to market income is, we argue, due to the fact that as the household moves through the life cycle, market income tracks female market labour supply, which in turn responds to changes in the composition of the household's consumption demand as between market and domestic goods over the life cycle. Since increasing female labour supply is associated with a substitution of market for domestic consumption, 
the co-movement in market income and consumption is essentially driven by this process. We also argue that the puzzlingly large drop in post-retirement market consumption is readily explained once we take account of the large increase in time spent in domestic production that occurs in this phase. The fall in full consumption is much less sharp and rełects a moderate increase in pure leisure.

All this refers to the "average household". This paper has however placed major emphasis on the heterogeneity of households. Households with the same wage rates and demographic characteristics make widely dixering choices of female market labour supply. We attribute this to dixerences in human capital and productivity in household production. We also show that the dixerences in female labour supply are associated with large dixerences in saving, with a high propensity to save out of secondary earner income. We provide a formal life cycle model to capture these dixerences, and then calibrate a simpli..ed version of this model on the data. It is often argued that an increase in household income inequality, brought about by a reduction in the degree of progressivity of income taxation, will increase saving. We use the calibrated model to show that this does not happen, when the exect of the tax reform is to reduce the net wage of secondary earners, increase that of primary earners, and so redistribute net income from households with a high, to households with a zero-to-low female labour supply. In conclusion, we hope to have demonstrated the usefulness and relevance of the approach we adopt in this paper, for the analysis of issues of public policy. 


\section{Appendix A}

In this appendix we discuss the methods used to combine information from the ABS 1993 HES, 1994 IDS and 1992 TUS, for computing the data medians and means tabulated in section 2, estimating the demand system in section 5 and constructing the hypothetical data set for the simulations reported in section 6 . We also present the parameter estimates of the withinperiod demand system.

The data requirements of the empirical analysis include the usual microlevel information on within-period market consumption expenditure and net household income available in the HES. ${ }^{27}$ Information on wage rates is missing from the HES because it omits detail on hours of market work, recording only employment status de..ned as "employed full time", "employed part time", "unemployed" or "not in the work force". Detailed information on hours of market work is available in the IDS. Data on domestic work and pure leisure are available in the TUS but missing from both the HES and the IDS. As noted in Section 2, the ..rst step in combining information from these complementary data sets is to select matching samples of two-adult households from each. We then merge information on time use from the TUS with the data for each record in the HES and IDS matching samples, and we estimate a net wage for each partner. This allows us to compute full consumption and full income.

The data merging procedures are as follows. Records in the IDS sample are augmented with data on pure leisure from the TUS using a split-sample instrumental variables approach. ${ }^{28}$ We instrument for pure leisure using a regression model for each household type, specifying demographic, education and occupation variables as regressors. We then compute domestic hours of work by subtracting market hours from total time allocated to market and domestic work. The latter is obtained by subtracting pure leisure from an

\footnotetext{
${ }^{27}$ We follow the convention in the literature of computing "saving" as the residual between current consumption expenditure and net income (see, for example, Attanasio and Banks (1998) and Banks, Blundell and Tanner (1998)). The ABS (1995) takes the view that because HES income and expenditure estimates do not balance for individual households (for reasons listed on p.27) that the dixerence between average weekly expenditure and income cannot be considered as a measure of saving. However, we suggest that for the purposes of most studies, including those of the present, where the focus is on changes in the relationship between consumption expenditure and income, the dixerence between the two can provide useful insights into life cycle saving behaviour.

${ }^{28}$ For a detailed discussion of the approach see, for example, Angrist and Kruger (1992).
} 
overall time constraint, set at 5840 hours ( 16 hours a day for 365 days per year). ${ }^{29}$ Expenditure on the domestic good is computed as the product of the domestic work variable and the net wage. Full income is obtained as the product of this time constraint and the net wage.

The computation of the net wage for each partner involves a number of steps. We compute gross hourly earnings for participants from data on "the number of hours usually worked per week in main and second jobs" and "total annual 1993/ 94 earned income", and we also calculate a marginal tax rate for each adult from information on direct taxes. B ecause the income tax schedule is progressive, we predict a net wage for each partner, correcting for selectivity in the case of a non-participating female partner, based on a regression model in which the dependent net wage variable is calculated using an "average" marginal tax rate for each type of worker. Unless we make this adjustment we obtain implausibly high net wage rates for non-participants.

The HES matching sample is augmented with information on domestic work from the TUS and net wages from the IDS, again using instrumental variables. The domestic hours of work variable of each partner is instrumented for each household type using demographic characteristics and personal attributes. The net wage of each partner and, in turn, the net full income of the household, are computed as described for augmenting the IDS sample with information on the same variables.

The results for the parameters of the demand system are presented in Table A. The system is estimated on a sample of 1907 household records selected from the HES sample on the additional criteria that the household is non-traditional, the male partner is employed full time and both partners report positive incomes. Under these criteria, the sample excludes traditional households and all records in phase 6 . Each record is augmented with time use and net wage information following the procedures described above. In the policy simulations, retired households are assumed to have the same preferences as households in phase 5.

The results indicate that all coed cients, apart from those on the log of household size in phases 2 and 3 (in some cases), are signi..cant at the 5 per cent level.

\footnotetext{
${ }^{29}$ In empirical work on labour supply the convention is to compute non-market hours (typically referred to as "leisure") from an overall time constraint. Here we are implicitly following this convention because the model we estimate and the reforms simulations treat total time allocated to market and domestic work as the time constraint. This is consistent with our assumption of separability between pure leisure and full consumption.
} 


\section{R eferences}

[1] ABS (1995), 1993-94 Household Expenditure Survey, Catalogue No 6530.0, AGPS.

[2] Angrist, J.D. and A.B. Krueger (1992), "The Exect of Age at School Entry on E ducational Attainment: A n A pplication of Instrumental Variables with Moments from T wo Samples", J ournal of the American Statistical Association, 87, 328-336.

[3] Apps, P. F., and R. Rees, (1988). Taxation and the Household, J ournal of Public Economics 35, 355-369.

[4] Apps, P. F. and R. Rees, (1999a), Individual vs. J oint Taxation in M odels with Household Production, J ournal of P olitical Economy, 107, 393403.

[5] Apps, P. F., and R. Rees, (1999b), On the Taxation of Trade Within and Between Households, J ournal of Public E conomics 73, 241-263.

[6] Apps, P. F., and R. Rees, (1999c), Household Saving, Time Allocation and Taxation, Discussion Paper 15, Münchener Wirtschaftswissenschaftliche B eiträge, Ludwig M aximilians Universität M ünchen.

[7] Attanasio, O.P. and J. Banks (1998), Trends in Household Saving: A Tale of Two Countries, Working Paper Series No W 98/ 15, Institute of F iscal Studies, London.

[8] Banks, J., R. Blundell and S. Tanner (1998), Is There a Retirement Saving Puzzle? American Economic Review, 88, 4, 769-788.

[9] Baxter, M., and U. J. J ermann, (1999), Household Production and the Excess Sensitivity of Consumption to Current Income, American Economic Review, 89, 4, 902-920.

[10] Becker, G.S., (1976), The E conomic A pproach to Human B ehavior, University of $\mathrm{C}$ hicago Press, Chicago/ L ondon

[11] B enhabib, J ., R. Rogerson and R. Wright, (1991), Homework in M acroeconomics: Household Production and Aggregate Fluctuations, J ournal of Political E conomy, 99, 6, 1166-1187. 
[12] Blundell, R., M. Browning and C. M eghir (1994), Consumer Demand and the Life-Cycle Allocation of Household Expenditures, Review of Economic Studies, 61, 57-80.

[13] Deaton, A., (1992), Understanding Consumption, Clarendon Press, Oxford.

[14] Diamond, P., (1985), Comment, in Frontiers of Economics, K. J . Arrow and S. Honkapohja (eds), B asil Blackwell, Oxford.

[15] Heckman, J., (1974), Life Cycle Consumption and Labor Supply, American Economic Review, 64, 188-194

[16] Heckman, J., (1995). What Has Been Learned A bout Labour Supply in the Last Twenty Years? American Economic Review Papers and Proceedings $83,116-121$.

[17] King, M., (1985), The Economics of Saving, A Survey of Recent Contributions, in Frontiers of Economics, K. J. Arrow and S. Honkapohja (eds), Basil Blackwell, Oxford.

[18] McGrattan, E., R. Rogerson and R. Wright, (1997), An Equilibrium $M$ odel of the Business $\mathrm{Cycle}$ with Household Production and $\mathrm{Fiscal}$ Policy, International Economic Review, 38, 2, 267-290.

[19] Rupert, P., R. R ogerson and R. Wright, (1995), Estimating Substitution Elasticities in Household Production Models, Economic Theory, 6, 179193.

[20] R upert, P., R. Rogerson and R. Wright, (1996), Homework in Labor E conomics: Household Production and Intertemporal Substitution. Mimeo.

[21] Thurow, L., (1969), The Optimum Lifetime Distribution of Consumption Expenditure, American Economic Review, 59, 324-30. 


\section{TABLES}

TABLE 1 Median saving by stage in life cycle (\$ pa, 1993)

\begin{tabular}{|c|c|c|c|c|c|c|}
\hline $\begin{array}{c}\text { Life cycle } \\
\text { phase }\end{array}$ & $\begin{array}{c}\text { Net mkt } \\
\text { income } \\
1\end{array}$ & $\begin{array}{c}\text { Mkt cons } \\
\text { expend } \\
2\end{array}$ & $\begin{array}{c}\text { Saving } \\
\mathbf{1}\end{array}$ & $\begin{array}{c}\text { Full cons } \\
\text { expend } \\
4\end{array}$ & $\begin{array}{c}\text { Net full } \\
\text { income } \\
5\end{array}$ & $\begin{array}{c}\text { HES } \\
\text { cell size } \\
6\end{array}$ \\
\hline $\mathbf{2}$ & 307038 & 35343 & 4524 & 54338 & 119534 & 676 \\
\hline $\mathbf{3}$ & 36296 & 36659 & 416 & 81127 & 132546 & 726 \\
\hline $\mathbf{4}$ & 44460 & 42264 & 1872 & 76072 & 135435 & 771 \\
\hline $\mathbf{5}$ & 37076 & 33689 & 3172 & 65052 & 136974 & 969 \\
\hline $\mathbf{6}$ & 17212 & 20737 & -1664 & 56418 & 132980 & 1060 \\
\hline All & 33124 & 32466 & 728 & 71099 & 133223 & 5062 \\
\hline
\end{tabular}

TABLE 2 Mean hours of work and \# kids

\begin{tabular}{|c|c|c|c|c|c|c|c|}
\hline \multirow[b]{2}{*}{$\begin{array}{c}\text { Life cycle } \\
\text { phase }\end{array}$} & \multicolumn{3}{|c|}{ Male hours of work } & \multicolumn{3}{|c|}{ Female hours of work } & \multirow[b]{2}{*}{$\begin{array}{c}\# \text { kids } \\
7\end{array}$} \\
\hline & $\begin{array}{c}\text { Market } \\
1 \\
\end{array}$ & $\begin{array}{c}\text { Domestic } \\
3\end{array}$ & $\begin{array}{c}\text { Total } \\
3\end{array}$ & $\begin{array}{c}\text { Market } \\
4\end{array}$ & $\begin{array}{c}\text { Domestic } \\
5\end{array}$ & $\begin{array}{c}\text { Total } \\
6\end{array}$ & \\
\hline 1 & 1733 & 805 & 2538 & 1481 & 1244 & 2725 & - \\
\hline 2 & 1734 & 1503 & 3237 & 507 & 3838 & 4345 & 1.91 \\
\hline 3 & 1809 & 1317 & 3126 & 737 & 3149 & 3886 & 2.66 \\
\hline 4 & 1733 & 928 & 2661 & 1023 & 2150 & 3173 & 1.75 \\
\hline 5 & 1505 & 910 & 2415 & 773 & 1830 & 2603 & - \\
\hline 6 & 0 & 1479 & 1479 & 148 & 2027 & 2175 & - \\
\hline All & 1311 & 1112 & 2423 & 721 & 2402 & 3123 & - \\
\hline
\end{tabular}


TABLE 3 Median income, consumption and saving (\$pa,1993)

\begin{tabular}{|c|c|c|c|c|c|c|}
\hline $\begin{array}{c}\text { Life cycle } \\
\text { phase }\end{array}$ & $\begin{array}{c}\text { Net mkt } \\
\text { income } \\
1\end{array}$ & $\begin{array}{c}\text { Mkt cons } \\
\text { expend } \\
2\end{array}$ & $\begin{array}{c}\text { Saving } \\
\text { (a)Traditional households }\end{array}$ & $\begin{array}{c}\text { Full cons } \\
\text { expend } \\
4\end{array}$ & $\begin{array}{c}\text { Net full } \\
\text { income } \\
5\end{array}$ & $\begin{array}{c}\text { HES } \\
\text { cell size } \\
6\end{array}$ \\
\hline $\mathbf{2}$ & 28600 & 30844 & -1352 & 87074 & 129145 & $\mathbf{1 0 4 6}$ \\
$\mathbf{3}$ & 32188 & 33217 & -780 & 82613 & 129942 & 241 \\
$\mathbf{4}$ & 34320 & 33888 & -1924 & 73244 & 131490 & 176 \\
$\mathbf{5}$ & 32032 & 30011 & 1872 & 61267 & 131455 & 283 \\
\hline (b) Non-traditional PT households & & & & $\mathbf{7 6 4}$ \\
\hline $\mathbf{2}$ & 38324 & 35736 & 2444 & 88135 & 130067 & 189 \\
$\mathbf{3}$ & 42328 & 38974 & 1768 & 85402 & 131973 & 183 \\
$\mathbf{4}$ & 45240 & 43601 & 3900 & 79187 & 131846 & 210 \\
$\mathbf{5}$ & 46072 & 40239 & 7540 & 68964 & 129988 & 182 \\
\hline (c) Non-traditional FT households & & & & $\mathbf{6 6 5}$ \\
\hline $\mathbf{2}$ & 46696 & 37245 & 9024 & 83050 & 127266 & 121 \\
$\mathbf{3}$ & 51740 & 41644 & 9022 & 78232 & 131864 & 136 \\
$\mathbf{4}$ & 56810 & 48135 & 7228 & 78109 & 134376 & 218 \\
$\mathbf{5}$ & 54496 & 41897 & 9282 & 67671 & 132066 & 190 \\
\hline
\end{tabular}

TABLE 4 Mean hours of work and \# kids

\begin{tabular}{|c|c|c|c|c|c|c|c|}
\hline \multirow[b]{2}{*}{$\begin{array}{c}\text { Life cycle } \\
\text { phase }\end{array}$} & \multicolumn{3}{|c|}{ Male hours of work } & \multicolumn{3}{|c|}{ Female hours of work } & \multirow[b]{2}{*}{$\begin{array}{c}\text { \# kids } \\
7\end{array}$} \\
\hline & $\begin{array}{c}\text { Market } \\
1 \\
\end{array}$ & $\begin{array}{c}\text { Domestic } \\
2\end{array}$ & $\begin{array}{c}\text { Total } \\
3\end{array}$ & $\begin{array}{c}\text { Market } \\
4\end{array}$ & $\begin{array}{c}\text { Domestic } \\
5\end{array}$ & $\begin{array}{c}\text { Total } \\
6\end{array}$ & \\
\hline \multicolumn{8}{|c|}{ (a)Traditional households } \\
\hline 2 & 2241 & 1186 & 3427 & 65 & 4234 & 4299 & 1.90 \\
\hline 3 & 2384 & 1036 & 3420 & 131 & 3566 & 3697 & 2.75 \\
\hline 4 & 2261 & 788 & 3049 & 143 & 2669 & 2812 & 1.73 \\
\hline 5 & 2182 & 713 & 2895 & 21 & 2177 & 2198 & - \\
\hline \multicolumn{8}{|c|}{ (b) Non-traditional PT households } \\
\hline 2 & 2258 & 1307 & 3465 & 929 & 3609 & 4538 & 1.81 \\
\hline 3 & 2280 & 1187 & 3467 & 998 & 3023 & 4021 & 2.46 \\
\hline 4 & 2292 & 849 & 3141 & 1079 & 2233 & 3312 & 1.79 \\
\hline 5 & 2221 & 782 & 3003 & 1009 & 1808 & 2817 & - \\
\hline \multicolumn{8}{|c|}{ (c) Non-traditional FT households } \\
\hline 2 & 2287 & 1332 & 3619 & 2038 & 2932 & 4970 & 1.68 \\
\hline 3 & 2426 & 1018 & 3444 & 2122 & 2287 & 4409 & 2.22 \\
\hline 4 & 2350 & 905 & 3255 & 2055 & 1617 & 3672 & 1.75 \\
\hline 5 & 2232 & 817 & 3049 & 2070 & 1339 & 3409 & - \\
\hline
\end{tabular}


TABLE 5 Median saving by quartiles of net household and full income (\$pa,1993)

\begin{tabular}{|c|c|c|c|c|c|}
\hline Quartile & 1 & 2 & 3 & 4 & All \\
\hline \multicolumn{6}{|c|}{ (a) Net household income } \\
\hline Traditional \% & 76.9 & 52.8 & 23.1 & 15.8 & 42.3 \\
\hline$\overline{\text { Saving \$pa }}$ & -2080 & 260 & 3822 & 16666 & -468 \\
\hline 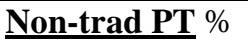 & 17.7 & 35.1 & 39.0 & 31.7 & 30.9 \\
\hline Saving \$pa & -3510 & 2090 & 5252 & 10738 & 3952 \\
\hline Non-trad FT $\%$ & 5.3 & 12.1 & 37.7 & 52.5 & 26.9 \\
\hline Saving \$pa & -6188 & 3536 & 7644 & 12948 & 8684 \\
\hline \multicolumn{6}{|c|}{ (b) Net full income } \\
\hline Traditional \% & 44.1 & 45.5 & 42.2 & 37.3 & 42.3 \\
\hline Saving \$pa & -1508 & -468 & 676 & 1508 & -468 \\
\hline Non-trad PT \% & 30.2 & 29.5 & 31.6 & 32.1 & 30.9 \\
\hline Saving \$pa & 520 & 2340 & 5720 & 6734 & 3952 \\
\hline Non-trad FT \% & 25.7 & 25.0 & 26.2 & 30.6 & 26.9 \\
\hline Saving \$pa & 4654 & 7124 & 9672 & 14300 & 8684 \\
\hline
\end{tabular}


TABLE 6 Pre-reform life cycle profiles (\$pa,1993)

\begin{tabular}{|c|c|c|c|c|}
\hline $\begin{array}{c}\text { Life cycle } \\
\text { phase }\end{array}$ & $\begin{array}{c}\text { Fem hrs } \\
\text { mkt work }\end{array}$ & $\begin{array}{c}\text { Net mkt } \\
\text { income } \\
2\end{array}$ & $\begin{array}{c}\text { Full cons } \\
\text { expend } \\
2\end{array}$ & $\begin{array}{c}\text { Saving } \\
3\end{array}$ \\
\hline
\end{tabular}

(a) Traditional households

\begin{tabular}{|c|c|c|c|c|}
\hline $\mathbf{1}$ & 1887 & 41556 & 55275 & 5247 \\
\hline $\mathbf{2}$ & 200 & 28635 & 86217 & -1352 \\
\hline $\mathbf{3}$ & 200 & 32007 & 82183 & -780 \\
\hline $\mathbf{4}$ & 200 & 33270 & 74550 & -1924 \\
\hline $\mathbf{5}$ & 200 & 30449 & 59834 & 1872 \\
\hline $\mathbf{6}$ & 0 & 12841 & 51067 & 0 \\
\hline
\end{tabular}

(b) Non-traditional PT households

\begin{tabular}{|c|c|c|c|c|}
\hline $\mathbf{1}$ & 1887 & 41556 & 55275 & 5247 \\
\hline $\mathbf{2}$ & 929 & 37200 & 87155 & 2444 \\
\hline $\mathbf{3}$ & 998 & 39458 & 83117 & 2768 \\
\hline $\mathbf{4}$ & 1079 & 42618 & 74305 & 3940 \\
\hline $\mathbf{5}$ & 1009 & 38302 & 59488 & 7540 \\
\hline $\mathbf{6}$ & 0 & 20060 & 58286 & 0 \\
\hline
\end{tabular}

(c) Non-traditional PT households

\begin{tabular}{|c|c|c|c|c|}
\hline $\mathbf{1}$ & 1887 & 41556 & 55275 & 5247 \\
\hline $\mathbf{2}$ & 2038 & 48295 & 85046 & 9054 \\
\hline $\mathbf{3}$ & 2122 & 52348 & 79915 & 9022 \\
\hline $\mathbf{4}$ & 2055 & 54315 & 77061 & 7228 \\
\hline $\mathbf{5}$ & 2070 & 53295 & 69787 & 9282 \\
\hline $\mathbf{6}$ & 0 & 33572 & 71788 & 0 \\
\hline
\end{tabular}


TABLE 7 Post-Reform 1 life cycle profiles (\$pa,1993)

\begin{tabular}{|c|c|c|c|c|c|}
\hline $\begin{array}{c}\text { Life cycle } \\
\text { phase }\end{array}$ & $\begin{array}{c}\text { Fem hrs } \\
\text { mkt work } \\
1\end{array}$ & $\begin{array}{c}\text { Net mkt } \\
\text { income } \\
2\end{array}$ & $\begin{array}{c}\text { Full cons } \\
\text { expend } \\
3\end{array}$ & Saving & $\begin{array}{c}\text { Tax } \\
\text { change } \\
5\end{array}$ \\
\hline
\end{tabular}

(a) Traditional households

\begin{tabular}{|c|c|c|c|c|c|}
\hline $\mathbf{1}$ & 1878 & 40613 & 54191 & 4478 & 855 \\
\hline $\mathbf{2}$ & 59 & 28304 & 83026 & -1443 & -1071 \\
\hline $\mathbf{3}$ & 33 & 31540 & 79643 & -811 & -1237 \\
\hline $\mathbf{4}$ & 41 & 32847 & 72781 & -1898 & -1276 \\
\hline $\mathbf{5}$ & 91 & 30463 & 58661 & 1852 & -1114 \\
\hline $\mathbf{6}$ & 0 & 12131 & 50357 & 0 & 0 \\
\hline
\end{tabular}

(b) Non-traditional PT households

\begin{tabular}{|c|c|c|c|c|c|}
\hline $\mathbf{1}$ & 1880 & 40637 & 53976 & 4693 & 857 \\
\hline $\mathbf{2}$ & 833 & 36579 & 83597 & 2623 & -344 \\
\hline $\mathbf{3}$ & 875 & 38515 & 80230 & 2734 & -330 \\
\hline $\mathbf{4}$ & 960 & 41606 & 72254 & 3687 & -276 \\
\hline $\mathbf{5}$ & 934 & 37710 & 58090 & 7158 & -196 \\
\hline $\mathbf{6}$ & 0 & 19022 & 57248 & 0 & 0 \\
\hline
\end{tabular}

(c) Non-traditional FT households

\begin{tabular}{|c|c|c|c|c|c|}
\hline $\mathbf{1}$ & 1883 & 40656 & 53805 & 4864 & 859 \\
\hline $\mathbf{2}$ & 1979 & 46868 & 81315 & 8923 & 833 \\
\hline $\mathbf{3}$ & 2045 & 50678 & 76893 & 8705 & 864 \\
\hline $\mathbf{4}$ & 1985 & 52718 & 74697 & 6911 & 831 \\
\hline $\mathbf{5}$ & 2046 & 52137 & 67932 & 8776 & 891 \\
\hline $\mathbf{6}$ & 0 & 32069 & 70285 & 0 & 0 \\
\hline
\end{tabular}


TABLE 8 Post-Reform 2 life cycle profiles (\$pa,1993)

\begin{tabular}{|c|c|c|c|c|c|}
\hline $\begin{array}{c}\text { Life cycle } \\
\text { phase }\end{array}$ & $\begin{array}{c}\text { Fem hrs } \\
\text { mkt work } \\
1\end{array}$ & $\begin{array}{c}\text { Net mkt } \\
\text { income } \\
2\end{array}$ & $\begin{array}{c}\text { Full cons } \\
\text { expend } \\
3\end{array}$ & Saving & $\begin{array}{c}\text { Tax } \\
\text { change } \\
5\end{array}$ \\
\hline
\end{tabular}

(a) Traditional households

\begin{tabular}{|c|c|c|c|c|c|}
\hline $\mathbf{1}$ & 1900 & 42426 & 56263 & 5982 & -746 \\
\hline $\mathbf{2}$ & 326 & 28942 & 89192 & -1194 & 954 \\
\hline $\mathbf{3}$ & 346 & 32416 & 84534 & -728 & 1085 \\
\hline $\mathbf{4}$ & 337 & 33603 & 76173 & -1977 & 1134 \\
\hline $\mathbf{5}$ & 296 & 30358 & 60904 & 1836 & 1066 \\
\hline $\mathbf{6}$ & 0 & 13483 & 51709 & 0 & 0 \\
\hline
\end{tabular}

(b) Non-traditional PT households

\begin{tabular}{|c|c|c|c|c|c|}
\hline $\mathbf{1}$ & 1896 & 42396 & 56478 & 5766 & -744 \\
\hline $\mathbf{2}$ & 1016 & 37762 & 90508 & 2314 & 316 \\
\hline $\mathbf{3}$ & 1005 & 40325 & 85823 & 2822 & 254 \\
\hline $\mathbf{4}$ & 1182 & 43526 & 76213 & 4083 & 209 \\
\hline $\mathbf{5}$ & 1076 & 38809 & 60783 & 7869 & 201 \\
\hline $\mathbf{6}$ & 0 & 21018 & 59244 & 0 & 0 \\
\hline
\end{tabular}

(c) Non-traditional FT households

\begin{tabular}{|c|c|c|c|c|c|}
\hline $\mathbf{1}$ & 1894 & 42373 & 56650 & 5595 & -741 \\
\hline $\mathbf{2}$ & 2091 & 49637 & 88585 & 9222 & -792 \\
\hline $\mathbf{3}$ & 2190 & 53913 & 82766 & 9340 & -847 \\
\hline $\mathbf{4}$ & 2116 & 55787 & 79280 & 7512 & -796 \\
\hline $\mathbf{5}$ & 2095 & 54339 & 71523 & 9734 & -772 \\
\hline $\mathbf{6}$ & 0 & 34973 & 73189 & 0 & 0 \\
\hline
\end{tabular}


TABLE 9 Gains (losses) by quartiles of net household income in life cycle phases 2 to 5

\begin{tabular}{|c|c|c|c|c|c|}
\hline Quartile & 1 & 2 & 3 & 4 & All \\
\hline $\begin{array}{l}\text { \# Traditional } \\
\text { \# Non-traditional PT } \\
\text { \# Non-traditional FT }\end{array}$ & 3 & $\begin{array}{l}1 \\
2\end{array}$ & $\begin{array}{l}2 \\
1\end{array}$ & 3 & $\begin{array}{l}4 \\
4 \\
4\end{array}$ \\
\hline $\begin{array}{l}\text { Pre-reform } \\
\text { Net market income }\end{array}$ & 30461 & 35739 & 41811 & 53514 & 41338 \\
\hline$\frac{\text { Post-Reform 1 }}{\text { Net \$ gain (loss) pa }}$ & 1137 & 826 & 52 & -861 & 198 \\
\hline$\frac{\text { Post-Reform 1 }}{\text { Net \$ gain (loss) pa }}$ & -1042 & -726 & 33 & 797 & -169 \\
\hline
\end{tabular}


Table A Within-period demand system parameters

\begin{tabular}{|c|c|c|c|}
\hline $\begin{array}{c}\text { Life cycle } \\
\text { phase }\end{array}$ & Parameter & Estimate & (Std error) \\
\hline \multirow{3}{*}{1} & $\alpha_{y}$ & 0.2194 & $(0.0146)$ \\
\hline & $\gamma_{\mathrm{yy}}$ & 0.1327 & $(0.0038)$ \\
\hline & $\beta_{\mathrm{y}}$ & -0.1031 & $(0.0067)$ \\
\hline \multirow{6}{*}{2} & $\alpha_{\mathrm{y}}^{0}$ & 0.5348 & $(0.0190)$ \\
\hline & $\alpha_{\mathrm{y}}{ }^{1}(\operatorname{lnd})$ & 0.1177 & $(0.0238)$ \\
\hline & $\gamma_{\mathrm{yy}}{ }^{0}$ & 0.1084 & $(0.0224)$ \\
\hline & $\gamma_{\mathrm{yy}}^{1}(\operatorname{lnd})$ & -0.0155 & $(0.0336$ \\
\hline & $\beta_{\mathrm{y}}^{0}$ & -0.2696 & $(0.0192)$ \\
\hline & $\beta_{\mathrm{y}}{ }^{1}$ (lnd) & -0.0307 & $(0.0290)$ \\
\hline \multirow{6}{*}{3} & $\alpha_{y}^{0}$ & 0.4311 & $(0.0189)$ \\
\hline & $\alpha_{\mathrm{y}}{ }^{1}(\operatorname{lnd})$ & 0.0152 & $(0.0225)$ \\
\hline & $\gamma_{y y}{ }^{0}$ & 0.0767 & $(0.0279)$ \\
\hline & $\gamma_{\mathrm{yy}}{ }^{1}$ (lnd) & 0.0912 & $(0.0321)$ \\
\hline & $\beta_{\mathrm{y}}^{0}$ & -0.2163 & $(0.0273)$ \\
\hline & $\beta_{\mathrm{y}}^{1}(\operatorname{lnd})$ & -0.0559 & $(0.0297)$ \\
\hline \multirow{6}{*}{4} & $\alpha_{y}^{0}$ & 0.3165 & $(0.0093)$ \\
\hline & $\alpha_{\mathrm{y}}{ }^{1}(\operatorname{lnd})$ & 0.0882 & $(0.0162)$ \\
\hline & $\gamma_{\mathrm{yy}}^{0}$ & 0.1085 & $(0.0225)$ \\
\hline & $\gamma_{\mathrm{yy}}{ }^{1}$ (lnd) & -0.0155 & (0.0336 \\
\hline & & -0.1348 & $(0.0135)$ \\
\hline & $\beta_{\mathrm{y}}^{1}$ (lnd) & -0.0447 & $(0.0226)$ \\
\hline \multirow{3}{*}{5} & $\alpha_{y}$ & 0.3009 & $(0.0045)$ \\
\hline & $\gamma_{\mathrm{yy}}$ & 0.1234 & $(0.0061)$ \\
\hline & $\beta_{\mathrm{y}}$ & -0.1155 & $(0.0074)$ \\
\hline $\begin{array}{c}\log \mathrm{L} \\
\text { No records }\end{array}$ & & $\begin{array}{c}3368.51 \\
1907\end{array}$ & \\
\hline
\end{tabular}


Figure 1: Median saving by stage in life cycle (\$pa, 1993)

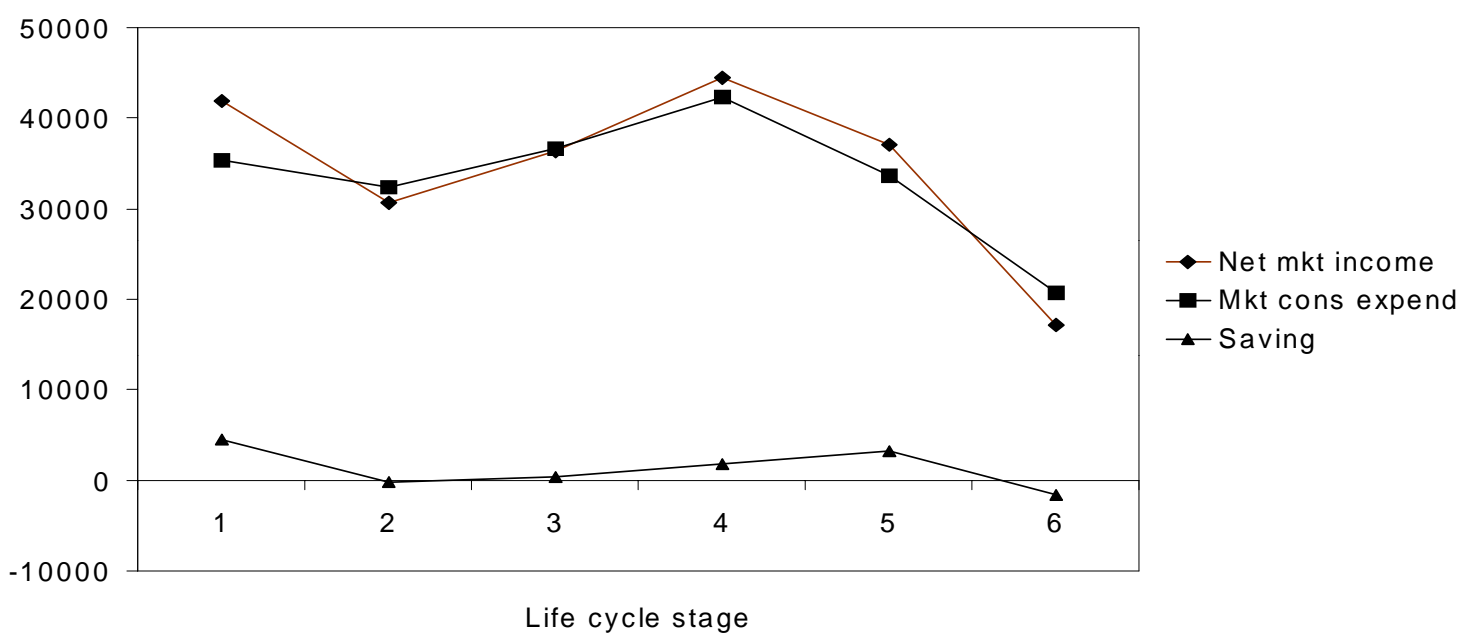

Figure 2: Full consumption expenditures / Full income (\$pa, 1993)

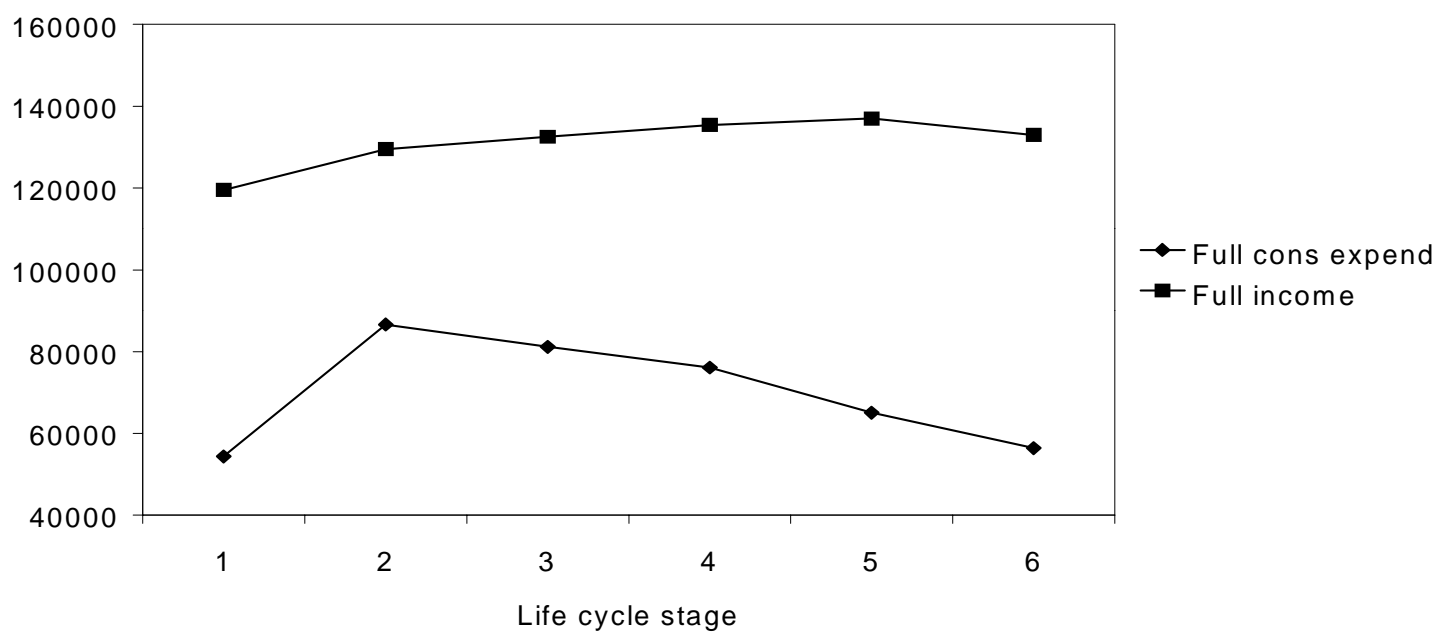


Figure 3: Mean hours of work

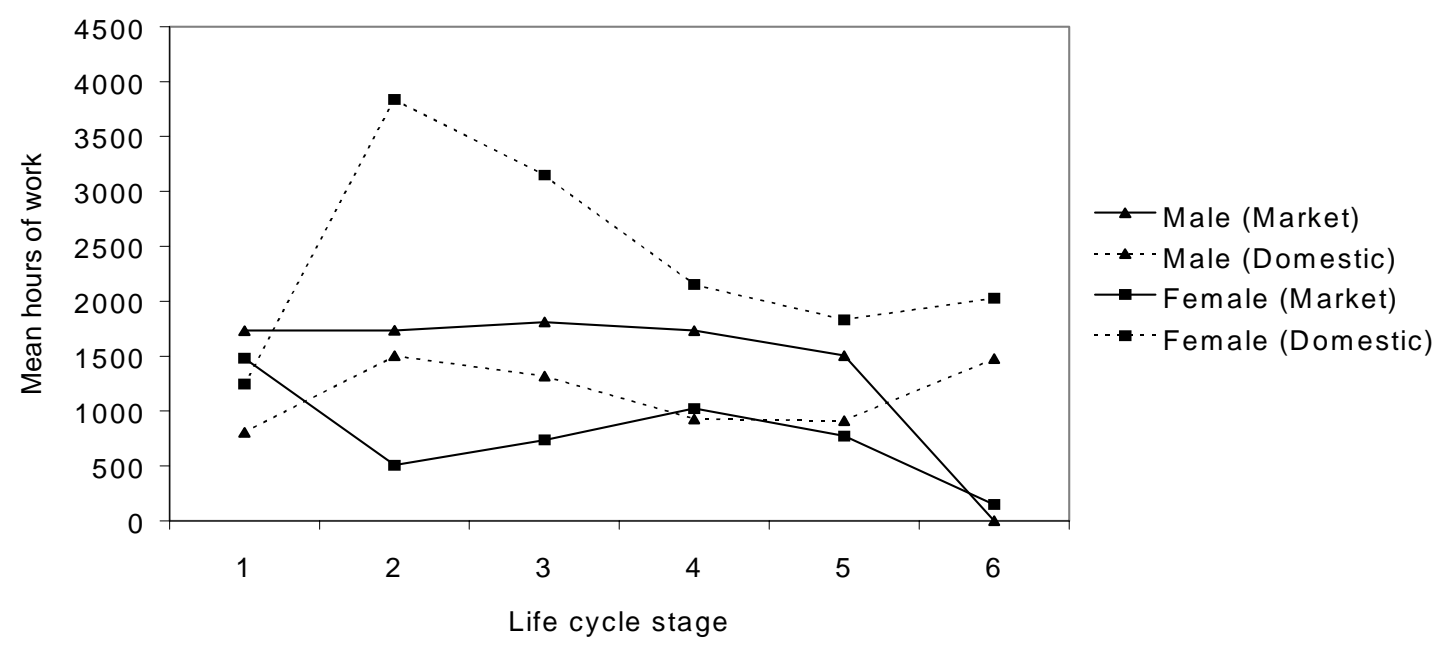


Figure 4: Saving by quartiles of net household income

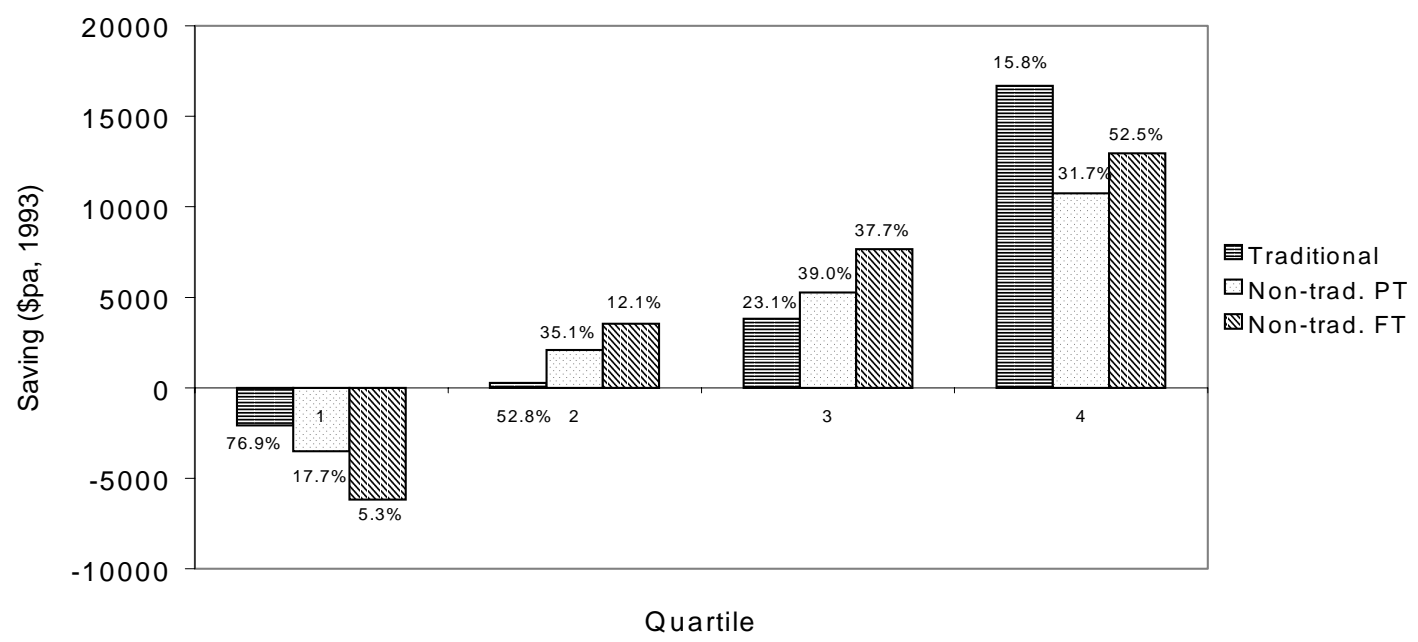

Figure 5: Saving by quartiles of net full income

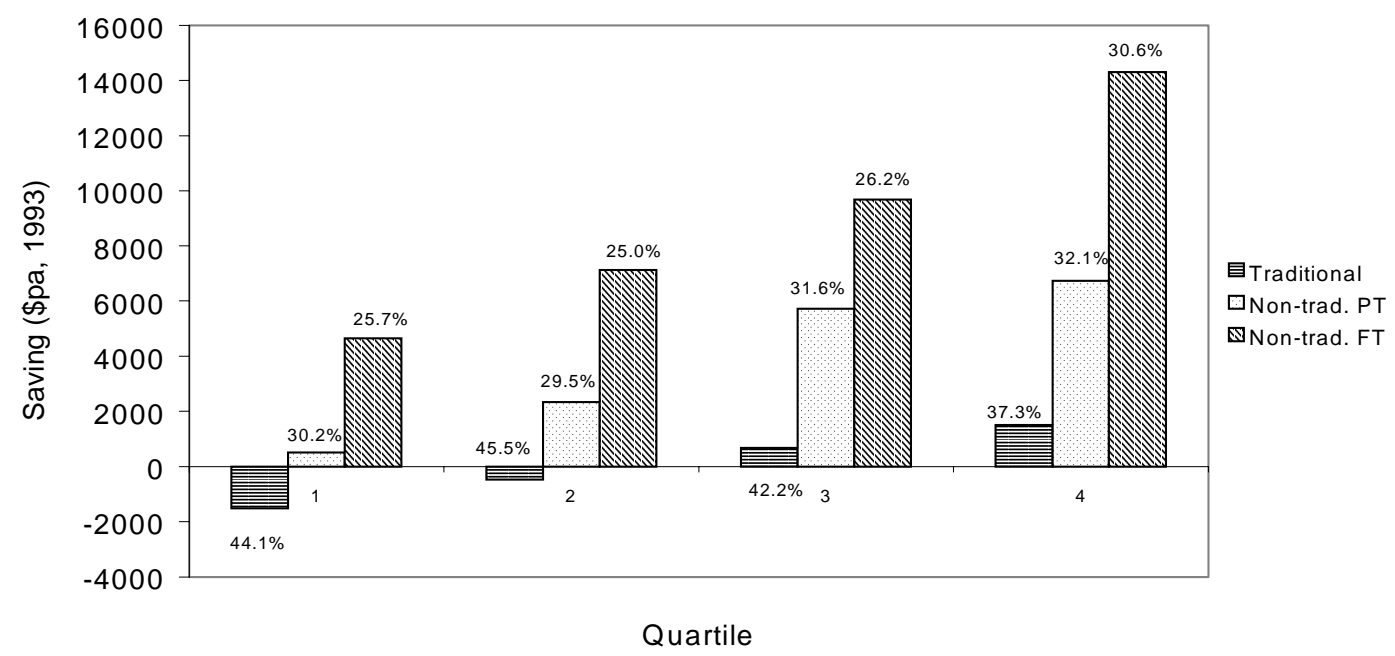

